\title{
Teen activism leads to local laws banning single-use plastics: a two-year experiential learning journey
}

\author{
Eleanor Burke ${ }^{1 *} \mathbb{D}$, Christopher Ciano Collins ${ }^{1}$, Lucy Bergeron $^{1}$ and Kara Lavender Law ${ }^{2}$
}

\begin{abstract}
This paper recounts the two-year journey of an eight-member public Massachusetts high school environmental club that set out to decrease their local community's consumption of single-use plastics. In the academic years 2016-2018, launched by a presentation by co-author Dr. Kara Lavender Law, the students wrestled with the global problem of plastic environmental debris within their local sphere of influence. They petitioned town government to regulate against local merchants' dispensing thin-film plastic bags or selling single-use plastic water bottles $<1 \mathrm{~L}$ in size. The journey called upon them to participate in the democratic process, and through it to inform the citizenry, entertain opposing viewpoints, counter strident opposition with facts, enlist allies, and build broad consensus. After a two-year process, the project arrived at a successful result. They learned through experience that with tenacity, they could make democracy work for their ethical ideals.
\end{abstract}

Keywords: Sustainability, Youth activism, Experiential learning, Plastic reduction, Environmental regulation, Environmental ethics

\section{Introduction}

"Marine debris is a global problem that requires collaborative solutions on both a global and local scale. There is no part of the world left untouched by marine debris and its impacts." (6IMDC 2018)

\section{The problem of plastic marine debris}

Marine debris, and notably debris composed of plastics, is recognized as a major environmental problem, as evidenced by its inclusion in international policy agendas from bodies including the UN, G7, G20 and the European Commission, as well as from many national, state and local governments. The concern is mainly on plastic debris because of the characteristics of these materials, namely: resistance to degradation and, thus, longevity in

\footnotetext{
* Correspondence: eleanor.burke.hardin@gmail.com

${ }^{1}$ Lincoln-Sudbury High School, Sudbury, MA, USA

Full list of author information is available at the end of the article
}

the environment; light weight, which allows plastic debris to be carried long distances by winds or in water; and harmful chemicals associated with plastics that are either incorporated during manufacture (e.g., as additives) or that are taken up by plastics from seawater (e.g., longlived DDT or PCBs). Among the most common forms of plastic debris, thin film plastic bags and one-use plastic water bottles are an unsustainable scourge for landfills, waterways, the world's oceans and aquatic life. The singleuse grocery bags we see on tree branches and fences, the "disposable" water bottles jammed in the storm grates on our streets, and the microbeads in our facial soaps are all examples of items comprising an estimated eight million metric tons of plastic waste that makes its way to the ocean from land each year [1], turning up even in samples from the 36,000-ft depths of the Mariana Trench, as reported in a National Geographic online post [2]. Rotting carcasses of malnourished fish, turtles, birds, and marine mammals whose stomach debris contains ingested plastics of all sizes and shapes routinely turn up on beaches.

(c) The Author(s). 2020 Open Access This article is licensed under a Creative Commons Attribution 4.0 International License, which permits use, sharing, adaptation, distribution and reproduction in any medium or format, as long as you give appropriate credit to the original author(s) and the source, provide a link to the Creative Commons licence, and indicate if changes were made. The images or other third party material in this article are included in the article's Creative Commons licence, unless indicated otherwise in a credit line to the material. If material is not included in the article's Creative Commons licence and your intended use is not permitted by statutory regulation or exceeds the permitted use, you will need to obtain permission directly from the copyright holder. To view a copy of this licence, visit http://creativecommons.org/licenses/by/4.0/. 
Scientific research is increasingly focused on very small plastic particles (microplastics and nanoplastics, which typically originate from the fragmentation of larger plastic items), the most numerous and widespread type of plastic debris in the environment. Because of their small size, these particles may be ingested by organisms ranging from whales to plankton. Further, scientists are concerned that these smallest particles could contaminate seafood species, potentially posing a risk to human health. The oceans have become a "plastic soup" in continent-sized gyres, where non-degrading plastic particles mix alongside plankton and are mistaken as food sources for animals.

A recent United Nations report states, "We are already unable to cope with the amount of plastic waste we generate, unless we rethink the way we manufacture, use and manage plastics. Ultimately, tackling one of the biggest environmental scourges of our time will require governments to regulate, businesses to innovate and individuals to act" $[3,4]$. Youth are exerting everincreasing pressure on local businesses and governments to take these steps, in response to what they see as a lack of adult leadership in matters of pollution and climate change. Figure 1. Is a NOAA Infographic depicting types of plastics found in the marine environment, some common sources and routes these take to the ocean, and some ways citizens can help reduce the problem.

\section{Research objective}

This is a report about the learning experiences of a group of eight environmentally minded youth who set out to change their local world for the better, by thinking globally and acting locally. Because their experiences took place in the real-world with all its human complexities, interactions, politics, unpredictability, emergent events, and zealous opponents and supporters, it is more amenable to a qualitative narrative, than to a scientific quantitative study where variables can be controlled.

However, neither is it fully a qualitative study. The students didn't start out with a defined research question, but rather just a sense of what is environmentally wrong in their hometown experience, and a desire to make it more right. In hindsight, we could say that their research question, or action goal, was this:

- We understand that plastic waste is becoming an environmental scourge, a toxin on land and in marine ecosystems. What would happen if we tried to create a law to ban single-use plastics in our towns? How would we go about it?

- Can we convince the powers that be and the towns' voters to sacrifice some conveniences and change the status quo? Can we make a difference in our environment by acting locally against this contaminant?

Their observations from everyday life led to a project (i.e. ban single use plastics), which led to learning about policy-making, which led to a process of creating policy, and every step of the way led them through new discoveries, understandings, re-interpretations of their reality. Along the way the students met obstacles, worked each problem, responded to emerging events, and stayed focused on their goal.

Borrowing from the conventional formatting of a qualitative research study, in this report the authors recount the students' experiences as they worked toward

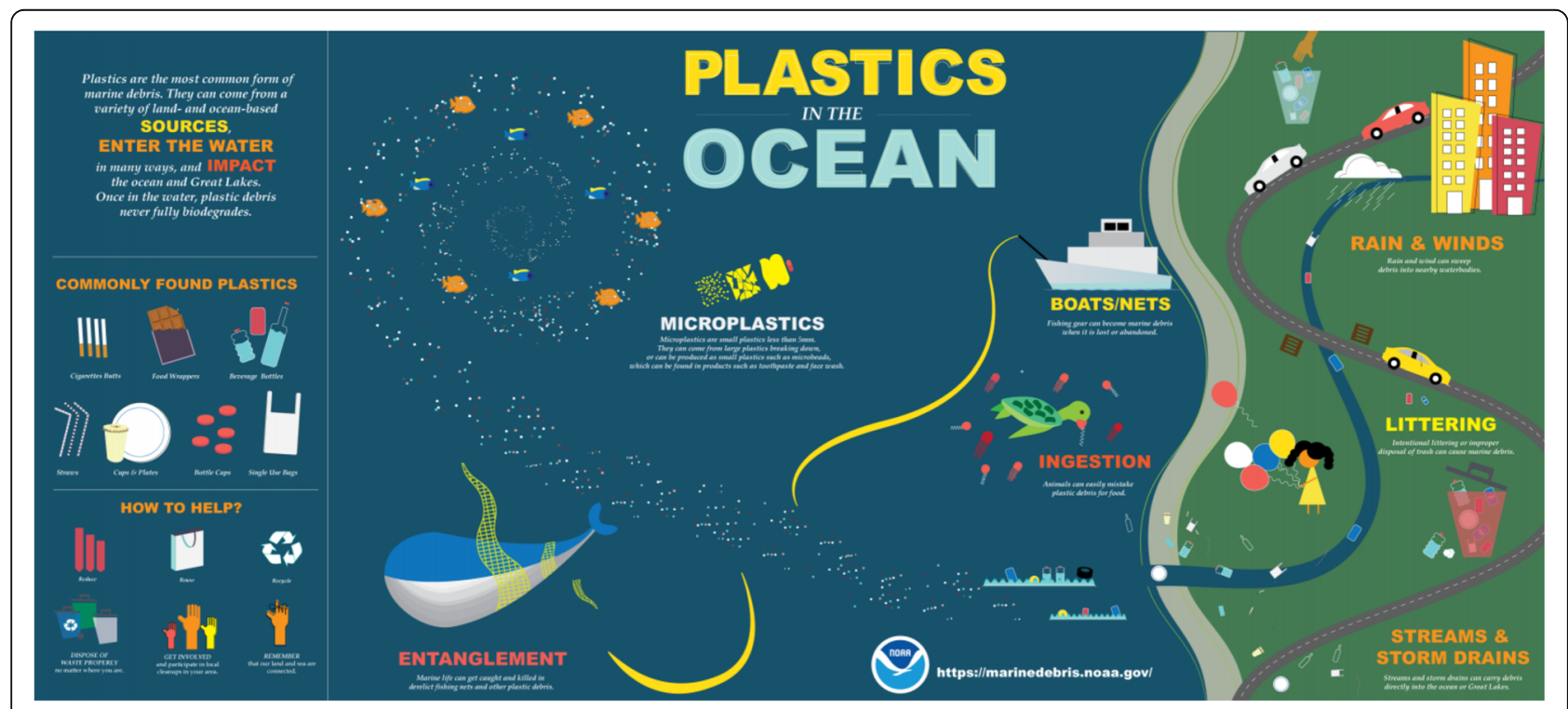

Fig. 1 NOAA Infographic: Plastics in the Ocean 
their objective, and we layer on the social constructs of meaning and perspective through "hindsight" reflections on the experience. This narrative is our reflection looking back on the journey, and trying to make sense of it in terms of the learnings the group took away, the meanings they attributed to them, and the relevance of these students' experience in the larger world of youth environmental activism.

Section 1 provides an overview of the problem and extent of plastic marine debris. Section 2 describes the student group's "research objective," or rather their action goal. In section 3 we provide background information about the school, the environmental club, and the processes used by local government to create laws. In section 4 we describe the students' methods and processes, and how these contributed to their learning. Section 5 discusses the lessons learned during the 2-year project, and section 6 lays out some ethical dilemmas the adult coaches encountered, with a section devoted to the ethical challenges a scientist faces at the interface where objective communication of scientific data meets personal belief in public activism. Section 7 summarizes the conclusions these reflections have led us to form, and situates the students' project in the larger movement of youth environmentalism.

In the time since the students' project, the United $\mathrm{Na}$ tions Environment Programme has published much information about these issues, including an appeal to schools and youth to "help turn the tide on plastic pollution," and a "Roadmap to Sustainability" concerning single use plastics $[3,4]$ These materials were not available to the club at the time they were carrying out their project, but will be cited throughout the discussion for retrospective interpretation.

\section{Background}

\section{The Lincoln-Sudbury high school environmental Club}

In Boston, Massachusetts' western suburbs, the two towns of Lincoln and Sudbury have a unified high school of about 1500 students. Extracurricular clubs meet outside of school hours with at least one faculty advisor, and students in these clubs are encouraged to determine, plan, and carry out their own agendas. The club's eight members, all female (the one male who started with the project was called to other commitments), ranged from 9th-12th grades, ages 14 to 18 . As of this writing, only one is still a minor. Most club members identified as caucasian, one as of Latin American parentage, and one of mixed south Asian/American parentage. During the years of the project, all had parental releases for every public appearance and news story written about them. Co-author Lucy Bergeron, the only student identified in this paper, is 19 at the time of this writing. It is worth noting that the students were not subjects in a study, but rather activists taking part in local civic life, and Lucy describes her own perspective here as a co-author. (Italicized sections labeled Student Perspective.)

In October 2016, the club's faculty advisors, coauthors Collins and Burke, invited co-author Dr. Kara Lavender Law, Research Professor of Oceanography at Sea Education Association (SEA) in Woods Hole, Massachusetts, to describe to the eight-member club her research findings about plastic marine debris. Dr. Law's talk raised the students' awareness about plastic debris detected worldwide in all major marine habitats, and concerns about risks to marine wildlife [5]. Photos of the impacts on wildlife motivated several members of the group, while others were moved by the story of an octogenarian woman in neighboring Concord, who managed to get the state's first municipal plastic bottle ban passed after two unsuccessful tries and a repeal battle. (See Dr. Law's slide presentation to the club, Additional file 1, appended to this paper.)

\section{Student perspective}

When I came to the first Environmental Club meeting in September of my junior year, I didn't know what to expect, or if I'd be coming back. I had spent my first two years of high school focused on academics, and while that was important, I figured I could benefit from extracurricular involvement at school. This led to my drifting from club to club, seeing what caught my attention, and stopping by when it happened to fit my schedule. I thought that was largely how the rest of my experience with clubs would be.

At that first meeting we looked at some work the club had done in recent years, such as a trash audit, and then brainstormed ideas for the coming year. As we filled the classroom whiteboard with ideas, it occurred to me that this club might have some potential. Dr. Law visited us soon afterward and shocked us with her presentation detailing the state of our oceans, particularly with photos of the so-called Great Pacific Garbage patch and the realities of microplastics. After having recently seen the results of the club's past trash audit, which showed our school's waste stream to be rife with plastic bottles, we felt responsible for the 'plastic soup' our oceans are undeniably becoming.

Writing and passing legislation didn't occur to us until we became familiar with the story of Jean Hill, the woman who created the plastic reduction bylaws in the neighboring town of Concord. We had added to our whiteboard the possibility of doing something about plastic, and were searching online for ideas on 
the best course of action, when we stumbled across her inspiring story. We got excited, realized our next town meetings were right around the corner in October, and I sent an email to the Lincoln Town office, asking for instructions on how to submit and pass a bylaw.

This was the start of a two-year experiential learning journey in environmental activism. Feeling compelled to take responsibility for local contributions to the problem, the students chose a point of best leverage against it: to curtail their two hometowns' generation of plastic waste in order to stop it entering the ocean. They created educational slideshows and took their show on the road to convince the voters of the school's two feedertowns that we must all think globally and act locally. They petitioned for new bylaws in both towns that would make it unlawful for merchants with retail areas of more than $325 \mathrm{~m}^{2}$ to sell single-use plastic water bottles or to provide thin-film plastic bags to shoppers.

\section{Local government: the town meeting}

Local governance in many New England towns has followed the open "Town Meeting" model ever since colonial times. In this tradition, any and all residents of voting age (18 years) can attend the meeting, voice opinions, deliberate, debate, and vote on local laws and budgets. Town Meeting governance is often described as the purest form of democracy, since no intermediary representation process exists between the voters and public decisions. Both Lincoln, MA and Sudbury, MA schedule an annual Town Meeting each spring to consider petitions for local bylaws and budgets; they hold a second "Special Town Meeting" in the fall to consider pressing issues and budget revisions.

The Town Clerk, a civil servant, visited the club and told the students that in order to place a petition for a new law at town meeting, they had to collect ten or more signatures of voters who supported their right to make the petition. They surpassed this goal, gathering more than 50 signatures in each town. Because the students in the Environmental Club were not yet 18 years of age, it was necessary for them to find an adult from each town to present their petitions at the forums; once these were presented, the students were free to speak and explain their rationale. By joining forces with existing local conservationist networks in town, the students found strong allies to support their presentations and to educate citizens via local news publications, lawn signs, and public forums.

At that time, only a handful of Massachusetts towns had any plastic restriction ordinances, and none had passed laws against both bottles and bags. The idea was scoffed at by many of the adults who first heard the students' presentation. A few members of the Boards of
Selectmen of the towns, who would have to approve putting the petition on the agenda, tried to dissuade the students from going forward with their project until they had spoken with more stakeholders and met with more town committee members. (From here on, we refer to the Board of Selectmen with the ungendered term Selectboard.)

\section{Methods and process}

The iterative experiential-learning process

The long and winding road that lay ahead was not readily apparent to the students of the Lincoln-Sudbury Environmental Club when they embarked on their plastics reduction campaign in the fall of 2016. The flow of their experiences, from research to execution, pushed the students into developing a growth mindset (termed by some as grit) in order to achieve their ultimate goals [6]. In this mindset, tenacity and continuous improvement are keys to success.

After each public appearance the students discussed the positive and negative feedback they received from the audience, revised their educational materials and presentations, and brainstormed to plan their next meeting. These students were also pursuing challenging secondary coursework, and could only spend about $45 \mathrm{~min}$ per week at club meetings working as a team on their project.

The students' learning process could be summarized as an iterative learning cycle: research and learn $==>$ create and make public presentations $==>$ reflect on feedback $==>$ revise materials $==>$ repeat. (Fig. 2).

Their process closely parallels what Kolb and Kolb [7] described as a four stage experiential learning cycle: experiencing, reflecting, thinking, and acting. Through this experiential learning sequence, the students learned to use the democratic process to move the town governments toward their aims.

When the group began planning to place these petitions on the legislative agendas of both towns, they assumed it would be a fairly simple and straightforward task. That is, the students and adult advisors saw this as a linear path from planning and writing of the warrant articles (petitions) to the formal presentation and voting. However, soon after the first drafts were written, it became apparent that the path to success would require ever increasing amounts of effort, learning, flexibility, and adaptation.

\section{Student perspective}

Looking back, I don't think we understood exactly what we were embarking on. In my mind, it would be a matter of essentially copying and pasting Concord's bylaw, and passing it at the upcoming October town meeting. That notion was quickly shattered by 


\section{Research and learn}

\section{$\pi$ \\ Revise materials to respond to feedback}

\section{Group meets to reflect on feedback from presentations}

Create and make public presentations

Fig. 2 The students' iterative learning process

the response I got from the Town Clerk's office, explaining to me that in Lincoln, bylaws aren't voted on until March, and then detailing all the different steps that go into creating legislation.

I remember being momentarily disappointed, but we'd been given what we'd originally been searching for: an action plan. We had a goal and a list of steps on how to reach it, and that was enough to get us started. We went around our neighborhoods, explaining what we were doing and gathering signatures to get our proposal on the agenda. We met at school on a Saturday morning to draft a bylaw against plastic bags, and then decided we might as well make a second one to cover bottles. We submitted our work and then presented it to the Lincoln Selectboard, nearing the end of the task list given to us by the Clerk's office. The last steps were to do some public outreach, attend the town meeting, and let people vote.

But we'd only just begun, and the Selectboard didn't hesitate to let us know it. Instead of realizing our goal in March like we expected, our hard work was rewarded with yet another to-do list, one that would take us a year to complete.

The fact that the students were preparing identical petitions for two separate towns created a bifurcated process. We will describe it here, and summarize the learning that took place across the two processes. In Fig. 3, a timeline depicts how these simultaneous processes unfolded.
The process in Lincoln; slowing things down to gain buyin

The process in the town of Lincoln was complicated by the procedures that were being dictated by the Selectboard, with the aim of educating and gaining buy-in from the citizenry and its leaders. The students enjoyed the support of community groups such as Mothers Out Front and the Climate Justice Ministry, but the Selectboard specifically required that the club formally present their argument to various town subcommittees, business owners and other stakeholders.

As the club approached the first Town Meeting in Lincoln in March of 2017, it was becoming clear that the Selectboard's support would be withheld until the complete list of prescribed procedures had been accomplished. Time was a factor, and it was not feasible for the students to be able to perform all of the tasks prior to the March meeting. As a result, and with pressure from the Selectboard, the club decided to remove their petition from a binding vote and have it listed as a "Sense of the Town" vote, effectively a non-binding straw poll. The students anguished over this decision, but in the end, this delay would give the club more time to complete the process being demanded of them by the Selectboard and bring their argument before the town meeting the following year (March, 2018) for a binding town vote. Figure 4 Depicts the students coming forward to speak publicly for the first time at this 2017 Town Meeting. Additional files 2, 3 , and 4 , appended to this manuscript, show three iterations of the students' presentations to Town Meetings. These were altered frequently, to incorporate feedback, each time showing more partnership support and consultation with stakeholders. 
October 2016

Club members heard Dr. Kara Lavender Law's presentation about plastic marine debris, and viewed the film "Divide in Concord," from which they learned of the two-year struggle to ban single-use bottles in Concord, MA.

November 2016

Club members decided to petition for both bottle ban and thin-film plastic bag ban in their two towns, Lincoln and Sudbury, MA.

January-February 2017

Club members gathered information from town governing bodies about the process for creating and submitting by-law petitions. At this point, the timelines diverged for the two towns.

$\begin{array}{ll}\text { LINCOLN SUDBURY } & \text { SUN }\end{array}$

Club presented petitions at the annual
Lincoln Town Meeting. In order to obtain
Selectboard support of their petition, they
opted to allow a "Sense of the Town" vote
rather than a formal yay/nay vote. A
non-binding Sense of the Town resolution
passed. The students realize this meant
they would have to return to the following
year's meeting for a formal vote, if they
wanted a binding law to take effect.

March 2017

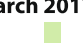

May 2017

With two months to improve their tactics since the Lincoln meeting, students presented their petitions at Sudbury Town Meeting. They had gained major backing from Sustainable Sudbury group, which funded yard signs and made get-out-the-vote phone calls for this meeting. To everyone's surprise, both measures passed into binding law!

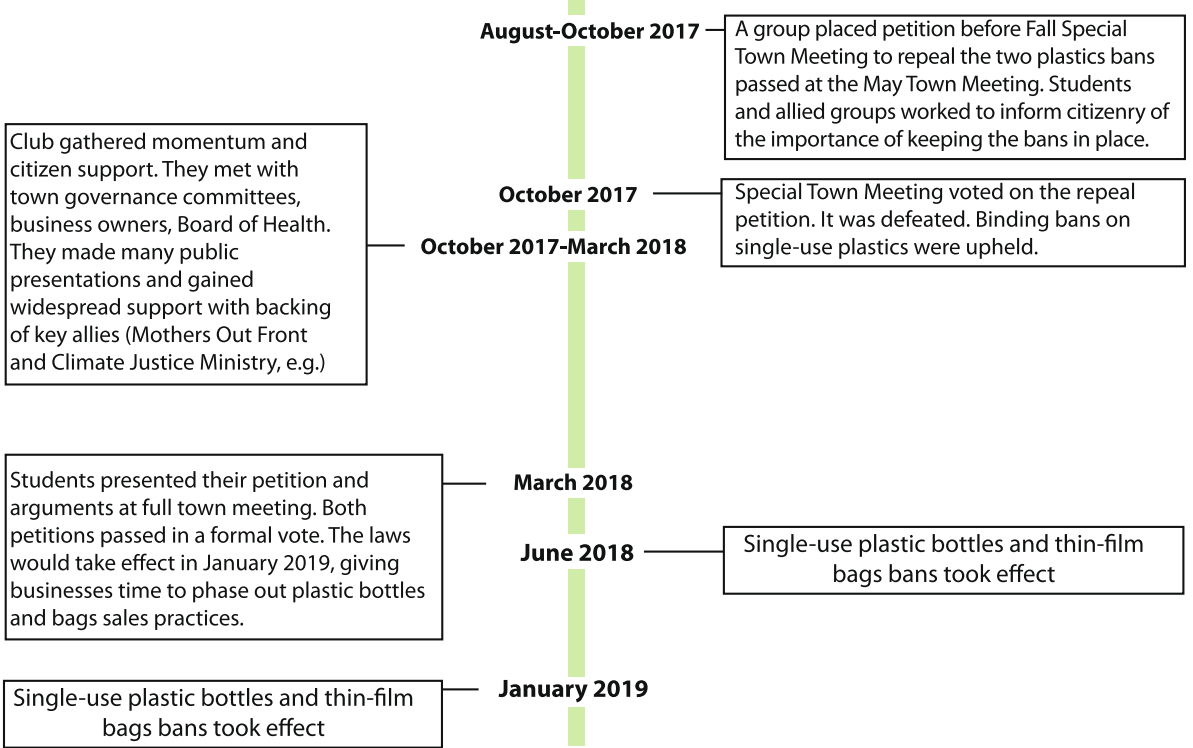

Fig. 3 Two-year timeline for enacting plastics bans

\section{Student perspective}

We came back to our classroom the Wednesday after, and talked about our options. Nothing required us to listen to the Selectmen's advice, so we could have just gone ahead and submitted our proposal for a vote at the Town Meeting. We basically had to decide if we were prepared to commit to another year of working on this project even though we had not foreseen it. I remember it being a long conversation where we weighed the pros and cons of our choices. We argued various points of view, but also reminded ourselves to stay positive and be proud of our work so far. We hadn't gotten the response from the Selectboard that we were hoping for, but we were given an opportunity to regroup and reconsider our approach. In the end, we decided to listen to the advice the Selectboard had given us, out of respect, and also because although it was frustrating to have our end-goal delayed, we hadn't necessarily disagreed with what they had said.

The club had its first real test when they presented to the Lincoln Town Meeting in March of 2017, as townspeople expressed a gamut of reactions from passionate support to irritated dismay at the consideration of both bag and bottle petitions during the open comment period. What had previously been an abstract planning 


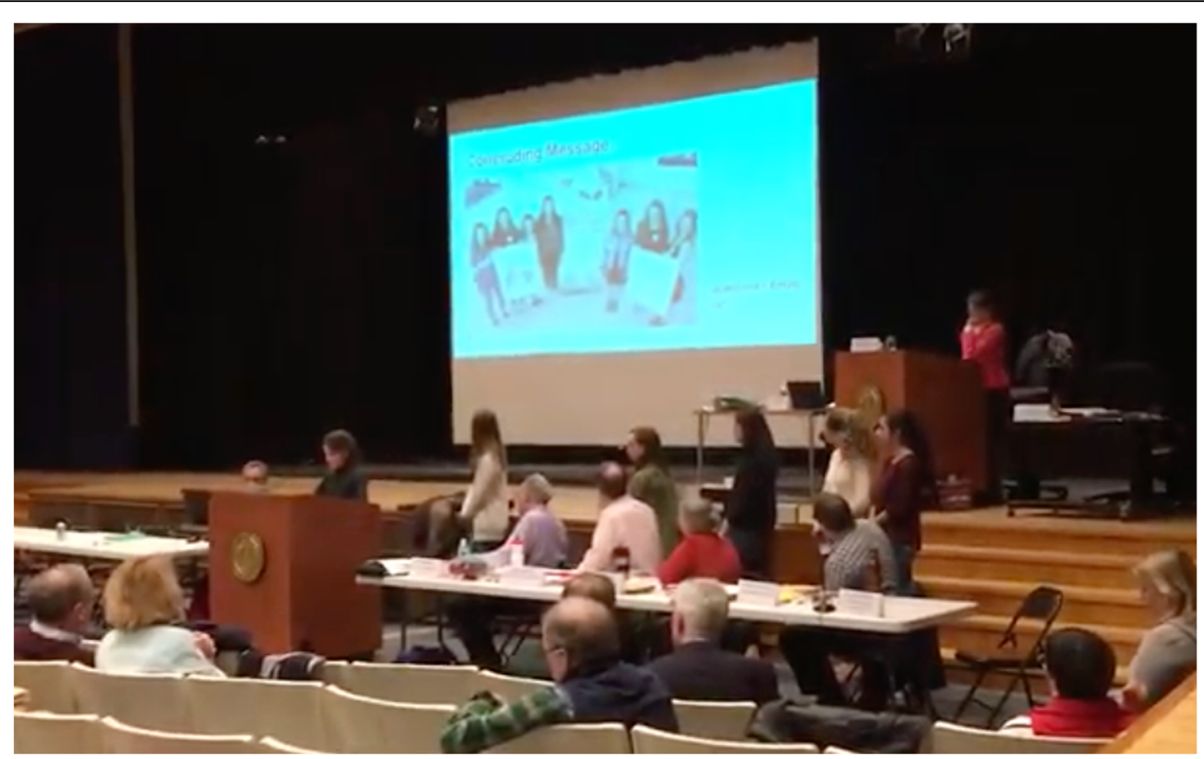

Fig. 4 Lincoln Town Meeting 2017

process in a vacuum of experience quickly exposed the students and their argument to a "pressure test" in public, and thus allowed them to refocus their efforts and argument in anticipation of future public meetings. It should be noted that during the informal "Sense of the Town" vote it became apparent to the club and their supporters that a majority of townspeople supported the petitions, and had the club made the choice to go forward with a binding vote, both would likely have been approved and adopted, despite some very vocal opposition. However, the Selectboard had warned that this would have created a divisive split in a town where consensus agreement is the preference. The students followed the board's suggestion and committed the time and effort needed to build community consensus. One year later, they would see that this prudent decision paid off: support grew over the 1 year period as the students increased their communication with constituents, and led to widespread acceptance and the eventual passage of the petitions. Without knowing it, this ensured that they were following step four of the UNEP ten-step roadmap (not yet published at the time), namely to foster stakeholder engagement through calling for "early inputs, policy discussion meetings, and wide-reaching awareness campaigns" [3].

\section{The process in Sudbury: getting the enforcement details right}

With the Lincoln Town Meeting experience behind them, the students turned their attention to Sudbury's process, which at first blush seemed much simpler in terms of what town government was expecting from the student-petitioners. Aside from one meeting with the Selectboard and having their presentation sent to the Finance Committee, very little was required of the school club prior to presenting their petitions before the town meeting in May of 2017.

A few bumps, however, did appear in the road. The Town Clerk's office and the Selectboard required some revisions in the wording of the petitions, the incorporation of comments from the Public Health officer, and a compromise on the effective dates of the petitions, should they be passed. This revision period promoted an evolution for the group. Reflecting on the mixed emotional experience of the previous town meeting in Lincoln, the students started to see how they must consider the viewpoints of all stakeholders and plan on concrete methods to address the concerns. They listened to the concerns of the Board of Health, which would have to enforce this bylaw if it passed, and from business owners fearful about the potential loss of revenue and the sales of bottled water stock already purchased. These coursecorrections proved to be crucial in gaining the support of town governance boards, and were (unwittingly) spoton with the step nine of the not-yet published UNEP roadmap for policymakers: to ensure that the process, timeline, and roles and responsibilities for enforcement are clear to those charged with this task [3].

The group had the support and assistance of Sustainable Sudbury, a community group that volunteered to shoulder a portion of the burden of the educational campaign. The students refined their approach, working very closely with key figures from Sustainable Sudbury. The once seemingly straightforward process that 
appeared to be their path at the start had become a deep-dive lesson in empathy and listening, as they folded the feedback and experience from the Lincoln meeting into their Sudbury preparations.

\section{Student perspective}

This setback [moving the enforcement date out by a year] wasn't too unbearable, however, since a few weeks later both our initiatives were voted into bylaws in Sudbury. This brought us a whole host of new problems to deal with, mostly convincing people who disagreed and supporting businesses as they transitioned away from the bags and bottles, but it was the success we needed to rally for another try in Lincoln.

Within a few weeks, the club was in front of the Town of Sudbury's annual meeting to present their petitions. Sudbury was originally presumed to be the tougher of the two towns to win over as a function of its larger population and more complex commercial setting. The students made their pitch and answered questions during the open comment period, assisted by the leaders of Sustainable Sudbury. This alliance was profoundly educational for the members of the club as they worked in union with Sustainable Sudbury members to address legitimate concerns around the petitions. The strength of this combination, along with Sustainable Sudbury's "get out the vote" efforts in the weeks leading to town meeting, proved critical to the club's mission. As a result, to the shock and elation of the club and its supporters, at $11 \mathrm{pm}$ just before adjournment, both bag and bottle petitions passed by a majority vote of the townspeople.

\section{Discussion: lessons learned}

Lesson 1: taking on other perspectives (e.g. the business sector)

In September of the second year of the project, challenges from the business sectors in both towns became the most formidable obstacles. The need to gain some level of buy-in from local merchants who viewed plastic bags and singleserve water bottles as essential mechanisms to please customers surfaced as a knotty challenge in both towns.

First, the club received word that a Sudbury business owner had submitted a petition to repeal the plastic bottle bylaw they had fought so hard to get passed the previous May. This repeal measure would be voted on at the Special Town Meeting in October. The prospect of returning to face an additional stressful town meeting was not something that the club was delighted to take on, but they rallied and teamed up yet again with Sustainable Sudbury to battle for the fledgling bylaw's survival.
In the wake of the past spring's meetings, club members deliberated the need to consider these issues not only from the environmental standpoint, but also from that of the business owner. They demonstrated with sample containers that if a business had to sell singleuse water bottles to maintain profit margins, it could do so with alternative containers (reusable bottles and refill stations, boxed water, aluminum containers) and thus mitigate the use and disposal of plastics while at the same time generating profit.

The students used the Sudbury repeal debate as an opportunity to experiment with promoting viable alternatives for single-use plastic bottles, in order to assuage the fears of business leaders. They appeared at the October Special Town Meeting, and in teamwork with Sustainable Sudbury, fielded questions in response to the proposed repeal. These joint efforts held sway, and the attempt to repeal the measure was defeated.

Lincoln's process in year two likewise presented a challenge from the business sector. A significant group of townspeople and merchants feared that banning single-use bottles would negatively affect and drive away the only grocery store in town. After a snowstorm in 2011 had collapsed a section of the store's roof, the town had experienced 2 years without the convenience of this local market during the repair period. Some people adamantly opposed the petition for fear of losing the grocery store altogether.

An unsolicited offer of assistance arrived from the singleuse aluminum water bottle company, Green Sheep Water (now called Open Water), out of Chicago, Illinois, after their CEO had read about the club's efforts the previous spring in Sudbury. This new partnership allowed the students to present to both towns' voters a financially viable alternative to plastic bottles, with concrete data from a forprofit company. Allied adult groups in both towns were instrumental in convincing voters that businesses would not suffer irreparable harm from the bag and bottle ban, despite a few business owners' refusal to meet with the students. This, incidentally, was in alignment with roadmap item six, "Support uptake of eco-friendly alternatives." [3].

\section{Lesson 2: adopting a growth mindset}

In the spirit of facing problems as learning experiences and growth opportunities, the students were cultivating a Growth Mindset [6]. Rather than feeling defeated by the setbacks, or intimidated by challenges from adults and business leaders, they maintained a firm conviction of the rightness of their cause, and determined to improve their case and their powers of persuasion.

This civic project in experiential learning provided fertile ground for the most noticeable area of growth since they had started their project. They had begun this journey with a staunch, if naive, conviction and a valid argument about the impacts of plastic pollution, which their 
youthful exuberance led them to assume would be shared by nearly all. Constant exposure to questions and critique from numerous parties drove the club to refine their materials, arguments, and debate tactics. In the process, they learned the difficult skills of involving multiple stakeholders, listening to viewpoints from a diverse body, and honing their public presentations to meet criticisms headon. Driven by a passion for their mission and for building greater environmental awareness among the townspeople, they soldiered on.

\section{Lesson 3: dealing with sometimes hostile opposition}

It became apparent at an early October meeting with the Selectboard that in order to build the wide consensus the Lincoln leadership wanted, the workload in year two would be daunting. On top of challenging academic loads and school schedules, the students were now tasked with presenting to more than two dozen committees, subcommittees, businesses, townspeople, and building managers between November and March. This schedule and the diversity of their audiences demanded almost constant reflection, experimentation, conceptualization, and trial by verbal fire in the public arena.

Week after week the students met with individuals and groups in an effort to build support for their petitions and to learn how to build the most robust plan for the March 2018 meeting. The meeting schedule was exhaustive, both for the time required and also because some of the groups were unsupportive of the petitions and at times disrespectful of the students themselves, their mission, and their aims.

At one meeting, for example, they were belittled by a speaker who proposed that scientists were closing in on a silver-bullet solution to the problem of marine plastic debris, by spraying the oceans with plastic eating bacteria. Why give up our contaminating conveniences, he reasoned, when science can remediate them with a technological solution? He made no acknowledgment that science has barely begun to explore the idea, nor of the risks of unintended consequences of scattering bacteria in the oceans, nor the greenhouse gas cost of plastic production, nor the importance of reducing human pollution at its sources; his monologue seemed on the edge of mockery of the students for their youth and optimism. In the face of such opposition, the students learned to practice reflection both in the moment and in the wake of each meeting, as they responded calmly, trusting their strengthened action plan.

\section{Student perspective}

The advice of the Lincoln Selectmen was basically to meet with every board and committee in Lincoln to discuss our initiatives. It was a difficult process, sometimes we had meetings multiple nights a week. Some met us with support, and others with opposition. We continued to regroup every Wednesday to review our progress and prepare for the next meeting. It was a long process, one that was at times tedious and at others, challenging.

At Lincoln's final binding vote in March 2018, the presentation and the debate period showed followers and critics alike how the students had grown from the time of their first meeting to what they hoped would be their last. The quality of their presentation and the strength of their argument had been honed through 15 months of meetings, presentations, feedback, and reflection. In the end, the Town of Lincoln joined with Sudbury in approving the plastic bottle and bag reduction bylaws, becoming the third and fourth Massachusetts communities to ban single-use plastic bottles and joining the growing ranks of more than four dozen that had banned the free distribution of single-use plastic bags.

\section{Lesson 4: was consensus-building worth all the effort? Student perspective}

In hindsight, I think our initiatives would have passed the first year had we not listened to the Selectmen. I suspect they were in part trying to test us, or teach us a lesson about what they called the "Lincoln way," which was basically the idea that democracy should be a slow process of building consensus, and in Lincoln it goes extra slowly.

Personally, I found the slow process of democracy more frustrating than good, in light of the fact that the rates of climate change and plastic production are not going slowly. However, by our second time at the Lincoln town meeting, we had identified our key supporters, people were more educated on the issue, and although we still had opposition, no one could argue that it had not been dealt with. In Sudbury, we paid for our early success by facing efforts to repeal our plastic bottle bylaw the following year. Either way, we were able to commit to the issue, work together, and see it through, which I think is what made us successful.

The students' frustration at the slow workings of democracy and policy making is a theme we hear repeated worldwide in the growing youth environmental movements $[8,9]$ The slow pace of the world's response to climate change is leaving the next generation of leaders with legitimate fears that the mountain of problems they will soon encounter may be insurmountable. 


\section{Ethical dilemmas inherent in the experiential teaching/learning process}

Ethical challenge 1: eliciting civil behaviors from quarrelsome opponents

Certain ethical questions emerged as the students increased their level of public political activism. No one publicly questioned the students' right to have a voice in the political process, but some townspeople in positions of power did try to discourage them from taking legislative action, and tried to downplay the importance of what "youngsters" might have to say. As advisors to the young activists, Burke and Collins felt a responsibility to help the students learn how to deal with naysayers and adults who might downplay their standing as civic actors.

For example, one instance where we as the adult advisors had to make the difficult decision to cross the line from supporter and coach to that of defender, was during a meeting with an official town board. One of the board members, the acting director for that evening, clearly did not support the students' petition. This person began a series of aggressive questions focused on obscure and non-pertinent details of the petitions. The club members answered each of these to the best of their abilities, but if the students did not have a full or detailed answer, the board member became more aggressive and challenging, even going so far as to tell one student harshly, "Don't look to your teacher for help." After several minutes of this behavior, we made the decision to intervene, because when an educational experience threatens to harm a student in any manner, be it physical or emotional, we have an ethical and professional responsibility to intercede. Collins respectfully and firmly demanded that the board member either ask a direct question of the students or let them go home for the evening. The situation was defused at that point and the students were allowed to leave the meeting shortly afterward. This experience left the students who were present somewhat shaken, but by weathering it they became more unflinching in pursuit of their cause.

\section{Ethical challenge 2: what is the teacher's role in experiential learning?}

A strong reason for our decision to stay behind the scenes was grounded in our philosophy of good teaching. Our combined years of experience teaching high school students has led us to a firm belief in the power of experiential learning. Although at intervals during the project, the students read plastics research and heard advice from experts, perhaps the best teacher was the actual experience of standing in front of an auditorium full of adults, presenting and defending findings, facts, and opinions. Just as a coach cannot run a race for an athlete, or a parent cannot take a math exam for a child, we felt that club advisors cannot and should not try to script the voices of student-activists. It was their journey. We chose to let them hold the reins, rather than trying to superimpose a more adult perspective on their presentations.

In this process, we observed their growth as presenters and the tremendous sense of efficacy and accomplishment they developed.

Each time they spoke in public or answered questions from the press, they became more sure of their answers, more confident in their own individual environmental ethics and value systems. We soon realized that they had no need of adult voices to speak for them. Had we spoken, it would have diminished the exhilaration of realizing that they had the power within them, and the ability to use it to effect change. It is important to consider the role of the teacher, guide, or coach in experiential learning, and to make conscious decisions about when to let the experience itself be the teacher. A good teacher knows when it is time to step back and let the student become the master. We saw that the time had arrived.

\section{Ethical challenge 3: communications with parents}

At the high school level, frequent communication with parents is still key to young adults' development. Parental permission is required when taking students on field trips or to public appearances or press interviews; we kept parents informed of the students' mission and experiences, so they could provide needed support when students encountered unpleasantness in public forums. Keeping the environment safe for learning is the unequivocal responsibility of the teacher. Although we could not prevent other adults in public meetings from making deprecating comments, we made it our job to help the students become impervious to such uncivil behaviors, and to know how to parry the comments of naysayers with unemotional responses; and we stepped in to stop abusive treatment when necessary. In the end, keeping parents informed of these events was key to maintaining our good relationship with them. They were as proud as we were (probably more so) to see their children participating in the public arena.

\section{Ethical challenge 4: conflict of interest restrictions for public school employees}

Massachusetts conflict of interest law [10] places some limits on political action by public employees in certain situations. The law states that teachers may engage in private political activity using their own private resources, when acting for themselves and not as agents of, or representatives of the school. The limiting language states, however, "a public employee may not use his public position to engage in political activity," (M.G.L.2011) since 
doing so might secure unwarranted privileges of substantial value not properly available to non-publicly employed persons. The law specifically applies this limit to issues involving town budget decisions, since the employee's salary is part and parcel of this process.

Although the bottle and bag issues did not involve town budget, per se, in recent years our district has hewn to the position that within the school walls, public school employees should remain neutral on political issues. Teachers may teach about controversy and civic action, as long as they present balanced and nuanced arguments on many sides of an issue, and allow students to form opinions independently. The experiential learning involved in this student project did exactly that. The students began their journey with a narrow view of their mission ("environmental plastics should be outlawed"); they broadened their understandings with every group and individual they met along the way, and learned about the complex economic and social issues that also undergird environmental and political decisions.

The Environmental Club is from a public school funded entirely with taxpayer money; as such, some opponents of the plastic regulations might understandably claim that the school, a public institution, was prohibited from taking any position on political matters. Although the students did not speak for the institution, they did in a sense represent it, as their name indicates: the LincolnSudbury Environmental Club. Burke and Collins walked a fine line in this matter: we were not residents of either Lincoln or Sudbury, thus we had no vote in Town Meetings, and could only speak if invited to do so by the Town Moderator. If we had lived in the town, we could have stated our individual opinions, as long as we did so as citizens, not as representatives of the school. As nonresident employees of the towns, we felt ethically obliged to take no public position on the students' petition; yet as environmentalists and advisors to this group of intrepid young activists, we obviously had strong personal feelings about the righteous importance of their project.

To resolve this dilemma, we opted to keep our work with the students behind the scenes. We coached them as they practiced and honed their presentations at club meetings; we helped them plan their responses to naysayers and prepare for negative feedback; we scheduled their appearances at various board meetings--the Selectboards, the Boards of Health, and local law enforcement; we scheduled interviews when the press contacted the school for information on their project. We acted as coaches, administrative assistants, and at times, a line of defense against the incivility of some adult opponents.

Others who do environmental civic work with teenagers should try to foresee any ethical issues and plan for them. The ethical requirements for public employees will differ from those of private or non-governmental organizations, so the voice and actions of adult leaders may play out differently in each case.

\section{Ethical challenges for academic researchers: science communication as a foundation for activism}

(A scientist co-author's perspective)

As a scientist researching ocean plastic pollution, a topic with tremendous public awareness and interest, I am frequently invited to share the latest science on ocean plastics with a variety of audiences. Often the invitation comes from a person or group that has already become aware of the problem and wants to learn more about the research underlying the current knowledge of its scale and scope. Although many high-level knowledge gaps exist about the sources, fate, exposure to and impacts of plastic debris in the marine environment, it has been widely argued that the available scientific information is sufficient to justify mitigation and/or prevention measures on local to global scales. Many audiences arrive with this starting assumption and, consequently, are especially interested in gaining a hopeful and reasonable answer to the question: "How are we going to solve this problem?" Further, in many instances, audience members are not simply passive receivers of information; rather, they are stakeholders who seek to engage actively in solution-making. As in many other problems of global sustainability, the collaboration between academic researchers and non-academic stakeholders, including the citizenry, is considered necessary to build a collective understanding of the problem as the basis to design and implement feasible actions to address it [11]. In this vein, I am eager to engage with interested citizens and stakeholders to facilitate this exchange of information. Consequently, I was happy to accept the invitation to speak with the students of the Lincoln-Sudbury High School Environmental Club.

In a typical presentation on ocean plastic pollution I spend most of my time correcting common misconceptions of the problem (e.g., that so-called garbage patches are "floating landfills" or "islands of plastic"), and then presenting quantitative results from my research on the amount of plastics in the ocean and their distribution, as well as on others' work about their impacts on wildlife. Throughout the presentation I discuss major outstanding knowledge gaps, and then often present an overview of strategies being pursued to solve the problem, taking care not to endorse or advocate for particular policy solutions. This approach stems from careful consideration of a scientist's role in public engagement, as informed by Pielke Jr. [12], who lays out four models ranging from "The Pure Scientist" to "Issue Advocate". Ultimately, Pielke argues, the role a scientist chooses is less important than an honest acknowledgment of that role in a given context, especially when the context is political in 
nature [13]. In practice, as during my visit to LincolnSudbury High School, I share my knowledge about policy actions at international levels (e.g., G7 Marine Litter Action Plan), at the US federal level (e.g., 2015 Microbead-Free Waters Act), and at municipal levels, including plastic bag bans. Finally, I share ideas about what individual citizens can do to help reduce plastic waste. In this context, I include myself in the category of "citizen" (who happens to have scientific expertise) and share the personal actions I take that include: carrying reusable containers; making purchasing decisions that reduce the use of plastic packaging; and, serving on my municipal Recycling Committee that, in 2017, supported local ordinances to charge a fee for all single-use retail bags and to ban the use of polystyrene foam in food service. By sharing the actions that I take in my own life to reduce plastic waste, including citizen engagement in local policymaking, my aim is to spur audience members to consider their own behaviors, while recognizing the fine line between leading by example and "stealth issue advocacy" [12]. I don't know that I always succeed in this goal, but I am pleased that after my visit the students at Lincoln-Sudbury High School became better educated about ocean plastic pollution and were motivated to pursue change in their local communities, not because they became passionate advocates (which they did), or because plastic bags and single-use plastic water bottles were banned (which they were), but because they became engaged citizens who saw their vision through to a successful outcome.

\section{Conclusions}

As the Lincoln-Sudbury environmental club began its work in 2016, they were unaware of the many similar projects seeking local legislative action that were occurring simultaneously on other campuses in the US and abroad. In a sense, serendipity led these eight students to become part of a growing youth movement seeking local governmental regulations to protect the planet they stand to inherit. As is so frequently the case in grassroots movements, especially where youth are concerned, the actors in this story were motivated by personal ethical sensibilities, with a fervor developed and nurtured entirely within their own group. While this isolated style of working is not the best way to scale up an effort, it is often the nature of the beast when working with a group that meets for only $1 \mathrm{~h}$ per week.

Teamwork with and support from sustainability networks in both towns was crucial to overcoming resistance, and proved invaluable in moving the students' petitions toward a successful vote. These groups used their extensive email lists to inform environmentally minded citizens of the student petitions and to get them to attend Town Meeting to speak and vote in favor of the plastic bag and bottle bans. Before the student petitions, these adults' groups had not been able to garner sufficient support for the idea of banning single use plastics in their towns. When eight idealistic young people were willing to research the topic, propose new regulations, and be the public face of a set of persuasive illustrated arguments for restricting the plastic waste stream, a fortunate symbiosis ensued.

Considering the notoriously cautious and deliberate culture of the New England civic temperament, the success of this student project is noteworthy. The club's action marked the leading edge of a "sea change" on the topic; as of June 2019, 121 Massachusetts towns and cities, including Boston, now have bag bans in place (MassGreenNetwork 2019). State legislators have considered making the ban statewide law, but this has not yet happened. In September, 2018, Dr. Law testified on this subject before the US Senate Committee on Environment and Public Works, stating, "To reduce the impact of man-made trash on the oceans, wildlife and human health, it is imperative that we prevent debris, especially that made of plastics, from entering the ocean....In some instances, where plastics are unnecessary for function...a mandated ban may be appropriate" [14]. These young activists may represent the avant-garde of a nationwide movement, as more states and localities are awakening to the need for such bans.

In their two-year David vs. Goliath struggle, a maxim often attributed to Margaret Mead (though with uncertain origin in her writings) inspired this powerful little group through their journey: "Never doubt that a small group of thoughtful, committed citizens can change the world." Eight thoughtful, committed teenagers raised the environmental awareness of 24,000 citizens in their hometowns. Built on the foundation of others' work before them, their work sent out a ripple that has spread throughout Massachusetts and beyond. The eight protagonists in this story were acting from their own convictions, somewhat unaware of the flowering youth movement that was emerging even as they carried out their local project.

In the year since their project was completed, we are seeing a burgeoning global youth movement aimed at provoking world leaders to awaken to the environmental injustices wrought by climate change and pollution. Each day's reports bring news of this movement, as "From Jakarta to New York City, children and teenagers are walking out of class and marching in the streets to demand action on climate change. And the world is taking notice ... [as] these young climate activists are using their moral authority as children, and their social-media savvy, to surf a rising tide of adult concern." [15] An internet search for youth environmentalists will take you to a multitude of inspirational stories around the world, such as the Bali NGO "Bye Bye 
Plastic Bags" formed by the Wijsen sisters in their preteen years [16]; or a list of 'youth activists to follow' on social media compiled for Earthday's website [8],; or these stories from the Guardian about activism in underreported areas of the world where the injustices of environmental degradation are felt most pointedly $[9,17]$.

This paper has documented one group's embarkation into public activism, and we hope it might help other groups of youth who want to guide the world's environmental course into an uncertain future. An area for follow-up work may be for future club members to survey the towns' citizens, merchants, sanitation departments, and governing boards to determine levels of comfort with the new laws (implemented in early 2019), and whether a beneficial reduction has occurred in the waste stream in the towns.

The youth of today stand to inherit unfathomable global problems that have been mounting inexorably since the industrial revolution began. Those of us who have the privilege of working with young people would be wise to listen to their urgent calls for environmental regulation and mitigation, and help them create platforms to make their voices heard.

\section{Supplementary information}

Supplementary information accompanies this paper at https://doi.org/10. 1186/s42055-020-00035-0.

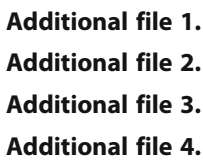

\section{Acknowledgements}

The authors are grateful to the many people and groups that supported their work and eventually led them to success, including the following: the staff and administration of Lincoln-Sudbury High school; the many members of town boards and governing bodies who led them through the complicated process of writing and passing laws; the merchants who met with them to discuss their misgivings about the proposed laws, and the citizens' environmental groups who supported them by creating lawn signs and other publicity, and who brought out the vote of environmentally minded folks on Town Meeting days. Three such groups deserving special mention are: Sustainable Sudbury, Mothers Out Front (Lincoln chapter), and the Climate Justice Ministry. We are particularly grateful to all those in the towns who listened to the students' messages and expressed their increased awareness of plastics pollution by voting for the proposed laws.

We also wish to thank the members of the Sustainable Earth guest editorial board who offered feedback on earlier drafts of the manuscript, especially David Crookall, Gillian Bowser, and Warren Thorngate. Their input helped shape and greatly improve the manuscript. We also thank the peer reviewers, whose excellent suggestions we have incorporated into this final ms. We also wish to thank Philip Hardin for graphic design of the timeline.

\section{Authors' contributions}

The co-authors each contributed sections to the account: high school faculty advisors EB and CC described the two-year process and the lessons and ethical dilemmas encountered along the way; former student LB authored all student perspective sections; and KLL provided the introduction to the science on plastic marine debris and a scientist's perspective on the ethical challenges inherent in the undefined areas where academic research meets environmental activism. The author(s) read and approved the final manuscript.

\section{Authors' information}

Eleanor Burke: Lincoln-Sudbury H. S. Associate Principal, Retired (2017); club co-advisor; MA Sustainability and Environmental Management, Harvard University Extension; M.Ed. Bilingual Education, Antioch University; BA. Spanish and Psychology, Duke University, Durham, NC.

Christopher Ciano Collins: Earth Science, Environmental Science, and Practical Physics teacher, Lincoln-Sudbury High School; club co-advisor; MA Climate \& Society, Columbia University; Post Bachelor Secondary Education, Bridgewater State University; BS Resource Economics and Commerce, University of Rhode Island.

Lucy Bergeron: club member; graduated 2018 Lincoln-Sudbury High School; attending the University of British Columbia in the fall of 2019, after a gap year living in France and doing environmental service work in Costa Rica. Kara Lavender Law: Research Professor of Oceanography, Sea Education Association, Woods Hole, MA. Ph.D. Physical Oceanography, University of California, San Diego/Scripps Institution of Oceanography, La Jolla, CA; BS Mathematics (Magna Cum Laude), Duke University, Durham, NC

\section{Funding}

Not applicable. This was a public school after-school club activity. All who participated in the experience and in writing about it were volunteers. This includes: faculty advisors at the high school, students in the club, co-author Dr. Law, the community groups who supported the students' efforts, and the town boards and governing bodies they met with.

\section{Availability of data and materials}

No data was collected during this journey in civic participation. All relevant materials are included in this paper.

Ethics approval and consent to participate

Not applicable. No "research" was conducted, thus no ethics approval or consent to participate was needed.

\section{Consent for publication}

The four authors of this manuscript give consent to publish it in Sustainable Earth special issue.

\section{Competing interests}

Not applicable.

\section{Author details}

${ }^{1}$ Lincoln-Sudbury High School, Sudbury, MA, USA. ${ }^{2}$ Sea Education Association, Woods Hole, MA, USA.

Received: 30 January 2020 Accepted: 19 August 2020

Published online: 22 September 2020

\section{References}

1. Jambeck, Geyer, Wilcox, Siegler, Perryman, Andrady, Narayan, and Law (2015) marine pollution: plastic waste inputs from land into the ocean Science 2015 Feb 13;347(6223):768-771 http://science.sciencemag.org/ content/347/6223/768

2. Nationalgeographic.com (NatGeo), "Microplastics found to permeate the ocean's deepest points," https://www.nationalgeographic.com/ environment/2018/12/microplastic-pollution-is-found-in-deep-sea/ Accessed 10 July 2019.

3. UNEP (2018a). SINGLE-USE PLASTICS: a roadmap for sustainability https:// wedocs.unep.org/bitstream/handle/20.500.11822/25496/singleUsePlastic_ sustainability.pdf?isAllowed=y\&sequence $=1$ accessed 10/14/19.

4. UNEP (2018b) United Nations Environment Programme News and Stories, "Back to School Plastic Challenge," 19 Sept. 2018. https://www unenvironment.org/news-and-stories/story/school-year-help-us-turn-tideplasticAccessed 10/14/19.

5. Law KL. Plastics in the marine environment. Annual Review of Marine Science. 2017;9(1):205-29. https://doi.org/10.1146/annurev-marine-010816060409

6. Dweck CS. Mindset: the new psychology of success. New York: Random House; 2006. 
7. Kolb, David \& Kolb, Alice. (2013). The Kolb Learning Style Inventory 4.0: Guide to Theory, Psychometrics, Research \& Applications.

8. Schnaidt, Isabel and Inma Galvez-Shorts, Earthday.org. 14 June 2019. https:// www.earthday.org/2019/06/14/15-youth-climate-activists-you-should-befollowing-on-social-media/.

9. Unigwe, Chika. "It's not just Greta Thunberg: why are we ignoring the developing world's aspiring activists?" The Guardian, 5 October 2019. https://www.theguardian.com/commentisfree/2019/oct/05/greta-thunbergdeveloping-world-activists Accessed 18 October 2019.

10. Massachusetts general law: GL c268A, section 23(b)(2)(ii). https://www.mass. gov/service-details/gl-c-268a-the-conflict-of-interest-law-as-amended-by-c-1 94-acts-of-2011 Accessed 20 Sept 2019.

11. Dedeurwaerdere T. Transdisciplinary sustainability science at higher education institutions: science policy tools for incremental institutional change. Sustainability. 2013;5:3783-801. https://doi.org/10.3390/su5093783.

12. Pielke RA Jr. The honest broker: making sense of science in policy and politics. Cambridge: Cambridge University Press; 2007. 188 pp.

13. Pielke, Jr., R. A., 2015. "Five modes of science engagement," blog post, http://rogerpielkejr.blogspot.com/2015/01/five-modes-of-scienceengagement.html Accessed 17 Sept 2019

14. Law, KL. Written testimony to US Senate Committee on environment and public works (2018). https://www.epw.senate.gov/public/_cache/files/9/8/ 98ff9257-c40b-4444-a890-22bff0d0a180/4088869BF694A5C3F1411C40B2 E6111F.law-testimony-09.26.2018.pdf Accessed 15 July 2019.

15. Marris, Emma. Why young climate activists have captured the world's attention. Nature international journal of science, news article, 18 Sept 2019 https://www.nature.com/articles/d41586-019-02696-0 Accessed 18 Oct. 2019.

16. Wijsen, Melati and Isabel. ByeBye Plastic Bags website, http://www. byebyeplasticbags.org/ Accessed 18 Oct. 2019

17. Turns, Anna. Meet generation Greta: young climate activists around the world. The Guardian. 28 June 2019 https://www.theguardian.com/ environment/2019/jun/28/generation-greta-young-climate-activists-aroundworld Accessed 18 Oct 2019.

\section{Publisher's Note}

Springer Nature remains neutral with regard to jurisdictional claims in published maps and institutional affiliations.

Ready to submit your research? Choose BMC and benefit from:

- fast, convenient online submission

- thorough peer review by experienced researchers in your field

- rapid publication on acceptance

- support for research data, including large and complex data types

- gold Open Access which fosters wider collaboration and increased citations

- maximum visibility for your research: over $100 \mathrm{M}$ website views per year

At $\mathrm{BMC}$, research is always in progress.

Learn more biomedcentral.com/submissions 